Additional services for The Classical Review:

Email alerts: Click here

Commercial reprints: $\underline{\text { Click here }}$

Terms of use : $\underline{\text { Click here }}$

\title{
COMMENTARIES ON THE METAPHYSICS
}

\section{R. W. Sharples}

The Classical Review / Volume 53 / Issue 02 / October 2003, pp 307 - 308

DOI: 10.1093/cr/53.2.307, Published online: 13 April 2006

Link to this article: http://journals.cambridge.org/abstract_S0009840X03002002

How to cite this article:

R. W. Sharples (2003). COMMENTARIES ON THE METAPHYSICS. The Classical Review,53, pp 307-308 doi:10.1093/ $\mathrm{cr} / 53.2 .307$

Request Permissions : $\underline{\text { Click here }}$ 


\section{COMMENTARIES ON THE METAPHYSICS}

\section{LunA: Trois études sur la tradition des commentaires anciens à la} Métaphysique d'Aristote. Pp. viii + 252. Leiden, Boston, and Cologne: Brill, 2001. Cased, €82. ISBN: 90-04-12074-2.

The corpus of surviving ancient and Byzantine commentaries on Aristotle includes four commentaries on the Metaphysics. We possess the commentary by the Peripatetic Alexander of Aphrodisias (c. 200 A.D.) on books $A-\Delta$; the continuation on books $E-N$, commonly since Praechter attributed to Michael of Ephesus (first half of the twelfth century A.D.); the commentary on books $B, \Gamma, M$, and $N$ by Syrianus (first half of the 5th century A.D.), the Neoplatonist teacher of Proclus; and the commentary on books $A-Z$ by Asclepius of Tralles recording the oral teaching of the later fifth/early sixth century A.D. Alexandrian Neoplatonist Ammonius son of Hermeias.

In this learned monograph, setting out and discussing nearly 200 pairs and triplets of parallel passages, L. examines the relations between these commentaries. Her work will be definitive for future work on them; it also makes valuable contributions to the general study of the methods of commentators in later antiquity. There are implications for the Orphic fragments (107 Kern: L. 9) and for those of Aristotle's lost works (Appendix II, pp. 193-6).

L. shows, by a detailed examination of all passages where there is either an explicit or an unacknowledged relation between the commentaries, that Syrianus knew and used the genuine commentary of Alexander (on $M N$ as well as $B \Gamma$; L., pp. 45-51), and that Asclepius combined material from Ammonius' lectures with (on $A-\Gamma$ only) direct use of Alexander's commentary, frequently thus reproducing the same material from Alexander twice. Ammonius used Syrianus' commentary directly, not just through oral 
tradition. Whereas Syrianus used his commentary as an opportunity to defend Plato against Aristotle's criticisms, Asclepius adopts a more conciliatory tone.

Leonardo Tarán has argued ('Syrianus and Pseudo-Alexander's Commentary on Metaphysics $E-N$ ', in J. Wiesner [ed.], Aristoteles, Werk und Wirkung; Paul Moraux gewidmet [Berlin, 1987], II, 215-32) that Pseudo-Alexander is earlier than Syrianus, and that the similarities between them are to be explained by Syrianus' use of Pseudo-Alexander, mistaken by him for the genuine Alexander. L. demonstrates that a detailed comparison of the parallel passages and of the two authors' knowledge of other texts suggests that it is Syrianus that is the source for Pseudo-Alexander rather than the reverse, and points out that T.'s thesis would imply that an otherwise unknown Peripatetic was the originator of a number of distinctive late Neoplatonist technical terms. It may be added that comparison of Pseudo-Alexander 706.31-707.2 and 706.8-15 with Simplicius, In Cael. 380.1-382.16 (cf. L., p. 67 n. 54) and 503.10-504.3, respectively, suggests that Pseudo-Alexander was using Simplicius (sixth century A.D.) rather than the reverse. (Cf. Th.-H. Martin, 'Questions connexes sur deux Sosigène ... et sur deux péripatéticiens Alexandre ...', Annales de la Faculté des Lettres de Bordeaux 1 [1879], 174-87, at 183; and my discussion in 'Pseudo-Alexander on Aristotle, Metaphysics Lambda', in G. Movia (ed.), Alessandro di Afrodisia e la Metafisica di Aristotele [Milan, 2003], pp. 187-218, at pp. 199-200 and 204-6 respectively.)

As for whether Pseudo-Alexander is to be identified with Michael of Ephesus, L., following Praechter, assembles an impressive quantity of evidence from linguistic usage (pp. 59-65, together with an extensive and valuable survey of Michael's distinctive usages in Appendix III, pp. 197-212).

There remains the question whether Freudenthal and Tarán were right to describe the author of the Pseudo-Alexander commentary as a 'forger', on the basis of the references back from the commentary on $E-N$ to that on $A-\Delta$ as if they formed part of the same work ('as has been said by me' or 'by us', 567.24, 630.31, 641.11, with L., p. 66; cf. also 'we have said' at 615.15 with L., p. 42 n. 80). L. defends Michael against this charge; to draw on earlier material was his regular method of compiling commentaries (one may compare Sten Ebbesen's memorable comparison of Michael to someone emptying the rubbish bag of a vacuum cleaner, in his 'Philoponus, "Alexander" and the Origins of Medieval Logic', in R. Sorabji [ed.], Aristotle Transformed: The Ancient Commentators and their Influence [London, 1990], pp. 445-61, at p. 448), and in referring back in this way to the commentary on $A-\Delta$ he was not intending to imply that his own commentary on $E-N$ was actually the original work of Alexander himself. The sheer scale of what L. rightly calls 'ce gros morceau' (p. 71) is, however, striking (439 pages in the Berlin edition!) compared with Michael's other borrowings from works by Alexander. And Michael may have jumped from the frying pan into the fire; acquitted of the charge of trying to pass off his own work as Alexander's, he risks the charge of claiming Alexander's work as his own. Paul Moraux, in his posthumous Der Aristotelismus bei den Griechen von Andronikos bis Alexander von Aphrodisias. Bd. III. Alexander von Aphrodisias, edited by J. Wiesner (Berlin, 2001), p. 354 n. 162, explained a parallel case at Michael (= [Philoponus]) In GA 88.7-9 (on which cf. L., p. 70 and n. 158, showing that the work there referred to is Philoponus $I n D A$ ) by suggesting that Michael regarded texts he had revised as his own productions. But in what sense could he claim that this was so for the commentary on $A-\Delta$ ? 